\title{
STUDI NARATIF MOTIVASI ORANGTUA MEMILIH LEMBAGA BIMBINGAN BELAJAR ANAK HEBAT UNIT 1418 DI DESA PLUNTURAN, PULUNG, PONOROGO
}

\author{
Rega Trendi Wijayanti \\ Fakultas Ushuluddin, Adab dan Dakwah IAIN Ponorogo \\ regatrendi14@gmail.com \\ Fadhilah Rahmawati \\ Fakultas Ushuluddin, Adab, dan Dakwah IAIN Ponorogo \\ fadhila.iainpo@gmail.com
}

\begin{abstract}
Abstact
This study aims to explore and find out the background of parents enrolling preschoolaged children into Great Children's tutoring, knowing the expectations of parents enrolling preschool-aged children into Great Children's tutoring, knowing the results of children's development after studying at Great Children's tutoring. This research uses qualitative research with descriptive narrative analysis method. The results of this study indicate that the background of parents enrolling their children in great children's tutoring is due to the motivation for achievement needs, the need for self-promotion (exhibition), the need to make others feel good (succorance), the need for order, and the need to balance. (counteraction).
\end{abstract}

Keywords: parental motivation, tutoring, needs

\begin{abstract}
Abstrak
Penelitian ini bertujuan untuk untuk menggali dan mengetahui latarbelakang orangtua mendaftarkan anak usia prasekolah ke bimbingan belajar Anak Hebat, mengetahui harapan orangtua mendaftarkan anak usia prasekolah ke bimbingan belajar Anak Hebat, mengetahui hasil perkembangan anak setelah belajar di bimbingan belajar Anak Hebat. Penelitian ini menggunakan jenis penelitian kualitatif dengan metode analisis deskriptif naratif. Hasil penelitian ini menunjukan bahwa latar belakang orang tua mendaftarkan anak ke bimbingan belajar anak hebat karena adanya motivasi kebutuhan berprestasi (achievement), kebutuhan penonjolan diri (exhibition), kebutuhan membuat orang lain iba (succorance), kebutuhan keteraturan (order), dan kebutuhan mengimbangi (counteraction).
\end{abstract}

Kata Kunci: motivasi orangtua, bimbingan belajar, kebutuhan 


\section{PENDAHULUAN}

Antusiasme orangtua yang sangat besar terhadap memilih lembaga bimbingan belajar untuk anaknya tentunya ada suatu motivasi tertentu. Saat ini orangtua juga sedang berlomba - lomba untuk memilih lembaga bimbingan belajar yang terbaik untuk anaknya karena orangtua sangat mempercayai lembaga bimbingan belajar bisa membantu meraka dalam mewujudkan impiannya terhadap anak mereka. Ditengah ramainya bimbingan belajar yang ada diwilayah kecamatan Pulung Kabupaten Ponorogo. Lembaga bimbingan belajar yang sekarang cukup terkenal di kecamatan Pulung adalah Anak Hebat. Siswa yang belajar di bimbel ini adalah anak usia prasekolah.

Dengan meningkatnya jumlah siswa disetiap tahunnya, maka saat ini bimbingan belajar telah menjadi trend dan telah menjadi suatu kebutuhan sehari - hari orangtua sebagai lembaga yang menjadi tempat anak untuk mendapatkan tambahan belajar diluar sekolah. Pilihan mendaftarkan anak di bimbingan belajar anak hebat membuat orangtua tidak merasa khawatir dengan perkembangan anak. Orangtua adalah pendidik dalam keluarga. Orangtua merupakan pendidik yang utama dan pertama bagi anak - anak mereka dari merekalah anak mula - mula menerima pendidikan. ${ }^{1}$

Orangtua seharusnya memahami bagaimana keadaan anak dan mendiskusikan dahulu bersama anaknya sebelum memasukkan anaknya pada sebuah bimbingan belajar karena hal ini sesuai dengan fungsi keluarga yaitu orangtua memiliki tanggung jawab untuk mendidik anaknya. Orangtua seharusnya mendampingi anak dalam belajar dan pengembangan potensi yang dimiliki anak. Orangtua hakikatnya adalah pendidik utama dimasyarakat dan pendidikan yang diberikan oleh orangtua kepada anaknya bersifat kodrati, akan tetapi orangtua lebih memilih dan percaya kepada bimbingan belajar dibandingkan dengan belajar dirumah bersama anaknya.

Dengan demikian berdasarkan data wawancara awal yang peneliti lakukan dengan hasil bahwa jumlah siswa Bimbingan Belajar Anak Hebat Unit 1418 mengalami kenaikan dari tahun ke tahun. Hal tersebut tercermin di setiap tahunnya terlihat orangtua

\footnotetext{
${ }^{1}$ Syaiful Bahri Djamarah, Pola Asuh Orangtua dan Komunikasi dalam Keluarga Upaya Membangun Citra Membentuk Pribadi Anak, (Jakarta: Rineka Cipta, 2014), 162
} 
berperan aktif dalam memasukkan anaknya ke Lembaga Bimbingan Belajar Anak Hebat. Berdasarkan hal tersebut dapat disimpulkan bahwa peran orangtua sangat tinggi untuk memasukkan anak ke lembaga bimbingan belajar Anak Hebat Unit 1418. Akan tetapi, belum diketahui motivasi apa yang mendorong orangtua memilih Lembaga Bimbingan Belajar Anak Hebat Unit 1418.

Dikarenakan belum pernah ada penelitian yang sejenis maka perlu dilakukan penelitian lebih lanjut untuk mengetahui motivasi orangtua memilih Lembaga Bimbingan Belajar Anak Hebat Unit 1418 Desa Plunturan Kecamatan Pulung Kabupaten Ponorogo tersebut peneliti termotivasi untuk melakukan suatu penelitian dengan mengangkat judul "Studi Naratif Motivasi Orangtua Memilih Lembaga Bimbingan Belajar Anak Hebat Unit 1418 di Desa Pluturan, Kec. Pulung, Kab. Ponorogo.

\section{Motivasi Orangtua}

Secara etimologis, motif atau dalam bahasa inggrisnya motive berasal dari kata motion yang berarti gerakan atau sesuatu yang bergerak. Jadi istilah motif erat berkaitan dengan gerak yakni gerakan yang dilakukan oleh manusia, atau disebut juga perbuatan atau tingkah laku. Motivasi atau dorongan memiliki peran yang sangat kuat dalam menemukan terwujudnya suatu perbuatan yang direncanakan. Dorongan itu dapat berupa imbalan atau adanya ancaman. Dorongan juga dapat terjadi sebagai bagian dari kesadaran jiwa yang diimbangi oleh harapan terhadap sesuatu yang akan dicapai ${ }^{2}$.

Motivasi dari sudut pandang teori belajar sosial. Dalam teori belajar sosial bahwa perilaku manusia ditentukan dari hasil belajar dari orang lain yaitu beberapa pola perilaku dipelajari melalui pengamatan terhadap perilaku orang lain dan observasi terhadap akibat yang ditimbulkannya ${ }^{3}$. Jenis perilaku yang ditunjukkan ikut menentukan ganjaran atau hukuman yang akan diterima dan pada gilirannya hal ini akan mempengaruhi perilaku manusia. Pola perilaku dapat diperoleh melalui pengalaman langsung atau melalui pengalaman terhadap respon orang lain.

\footnotetext{
${ }^{2}$ Rosleny Marliani, Psikologi Umum, (Bandung: Pustaka Setia,2010), 230.

${ }^{3}$ Rita L. Atkinson, Richard C Atkinson, Ernest R Hilgrad, Pengantar Psikologi Edisi ke delapan Jilid 2, (Jakarta: Erlangga 1996),55.
} 
Lingkaran Motivasi. Pada umumnya motivasi mempunyai sifat siklas (melingkar) yaitu motivasi yang timbul, memicu perilaku tertuju kepada tujuan, dan akhirnya setelah tujuan tercapai, motivasi itu berhenti ${ }^{4}$. Tetapi itu akan kembali ke keadaan semula apabila ada sesuatu kebutuhan lagi.

Jenis - jenis Motivasi. Desakan Kebutuhan Murray menggambarkan kebutuhan sebagai potensi atau kesiapan untuk merespon dengan cara tertentu dalam keadaan tertentu. Teori kebutuhan berdasarkan kebutuhan dan motivasi menunjukkan bahwa kepribadian kita adalah cerminan dari perilaku yang dikendalikan oleh kebutuhan.

Menurut Murray kebutuhan psikogenik berfungsi sebagian besar pada tingkat bawah sadar tetapi memainkan peran utama dalam kepribadian manusia. Murray mengemukakan suatu daftar duapuluh kebutuhan yang pada umumnya mendorong manusia untuk bertindak dan berperilaku. Namun disini penulis akan mencantumkan kebutuhan yang berkaitan dengan motivasi orangtua yaitu sebagai berikut ${ }^{5}$ : (a) Kebutuhan berprestasi (achievement), yaitu motivasi yang digunakan manusia untuk mengatasi sesuatu yang sulit dan menarik, menguasai, mengatasi rintangan dan mencapai standar, berbuat sebaik mungkin bersaing mengungguli orang lain; (b) Menggabung (affilation), yaitu kebutuhan untuk menyenangi kerjasama dengan orang lain, mendapat afeksi orang yang disenangi, menjadi teman akrab dari orang lain. Berbaik hati, berbuat sesuatu bersama dengan orang lain; (c) Mengimbangi (counteraction), yaitu kebutuhan memperbaiki kegagalan dengan berjuang lagi, menghilangkan pelecehan, mengatasi kelemahan, menekan takut, mengembalikan nama baik, mempertahankan harga diri; (d) Membela diri (defendance), yaitu kebutuhan untuk mempertahankan diri terhadap serangan, kritik, dan celaan, menyembunyikan atau membenarkan perbuatan tercela, menyembunyikan kegagalan, dan penghinaan; (e) Penonjolan diri (exhibition), yaitu kebutuhan untuk mengesankan, dilihat dan didengar, membuat orang lain kagum, bergairah, terpesona, terhibur, terkejut, terangsang, terpikat. Menjadi pusat prhatian, menonjolkan prestasi, menyatakan keberhasilannya; (f) Menghindari rasa hina (inavoidance), yaitu kebutuhan untuk menghindari penghinaan, keluar dari situasi yang

\footnotetext{
${ }^{4}$ Bimo Walgito, Pengantar Psikologi Umum (Yogyakarta:Andi 2004), 221.

${ }^{5}$ Alwisol, Psikologi Kepribadian (Malang: UMM Press 2009), 185 - 187.
} 
memalukan, kondisi yang bisa menimbulkan pelecehan, makian, ejekan, atau sikap masa bodoh. Menahan diri untuk bertindak karena takut gagal; (g) Merawat memelihara (nurturance), yaitu kebutuhan untuk memberi simpati, membantu, melindungi, menyenangkan orang lain yang tidak berdaya atau bayi atau orang yang lemah, membantu orang dalam bahaya. Untuk mengampuni dan berlaku dermawan kepada orang lain; (h) Keteraturan (order), kebutuhan untuk berbuat secara teratur dengan perencanaan yang cermat sebelumnya; (i)Keharuan (sentience), kebutuhan untuk memiliki dan menikmati keindahan, kesempurnaan yang abadi; (j) Membuat orang lain iba (succorance), yaitu kebutuhan ynag berkaitan dengan orang lain bersimpati dan membuat orang lain mengerti dan membantu dirinya. Kebutuhan dipandang sebagai kekuatan motivasi utama bagi seseorang dari sisi arah dan intensitas. Murray yakin bahwa kebutuhan lebih banyak diperoleh dari luar, bukan sesuatu yang diwarisi, dan diaktifkan oleh isyarat lingkungan luar

Macam - macam motivasi. Berdasarkan penyebabnya motif dibedakan menjadi dua yaitu motif intinsik dan motif ekstrinsik ${ }^{6}$. Motif instrinsik adalah motivasi yang dapat berfungsi tanpa harus dirangsang dari luar. Motif ekstrinsik adalah motivasi yang berfungsi karena adanya perangsang dari luar individu.

Orang tua merupakan pendidik utama dan pertama bagi anak - anak mereka. Dari merekalah anak mula - mula menerima pendidikan. Oleh karena itu, bentuk pertama dari pendidikan terdapat dalam kehidupan keluarga. Pendidikan yang diberikan oleh orang tua kepada anak bersifat kodrati. Jadi dapat disimpulkan bahwa orang tua merupakan orang yang bertanggung jawab dalam suatu keluarga atas rumah tangga dan tanggung jawab kepada anak - anaknya.

Keluarga merupakan lingkungan yang paling dekat dengan kehidupan anak. Peran orang tua yang lain adalah mengajarkan anak tentang nilai - nilai sosial, tradisi, prinsip, ketrampilan dan pola perilaku dalam segala aspeknya. Dalam hal ini orang tua

\footnotetext{
${ }^{6}$ Alex Sobur, Psikologi Umum dalam Lintasan Sejarah, (Bandung: Pustaka Setia,2003), 295 - 296.
} 
harus benar - benar berperan sebagai sarana pendidik dan pemberi nilai - nilai budaya yang mendasar dalam kehidupan anak. ${ }^{7}$

\section{Teori Perkembangan Anak Usia Prasekolah}

Menurut urutan waktu, masa kanak-kanak adalah masa perkembangan dari usia 2 hingga 6 tahun, pada masa anak-anak awal, anak banyak meniru, banyak bermain sandiwara ataupun khayalan, dari kebiasaaannya itu akan memberikan pengalamanpengalaman terhadap si anak. Namun antara anak dengan anak yang lainnya memiliki masa anak-anak awal yang berbeda-beda, hal tersebut karena perkembangan setiap anak berbeda-beda. disini peneliti akan menyebutkan tugas - tugas perkembangan anak usia prasekolah yang berkaitan dengan hasil perkembangan anak setelah belajar.

Perkembangan kognitif. Kognisi artinya kemampuan berfikir, kemampuan menggunakan otak. Perkembangan kognisi berarti perkembangan anak dalam menggunakan kekuatan berfikirnya. Dalam perkembangan kognitif, anak dalam hal ini otaknya mulai mengembangkan kemampuan untuk berfikir, belajar dan mengingat.

1) Tahap Pra-Operasional Piaget

Pemikiran pra-operasional adalah periode penantian yang nyaman untuk menuju tahapan berikutnya, yakni pemikiran operasional konkret. Tahapan pra-operasional, yang berlangsung kira-kira usia 2 hingga 7 tahun, adalah tahapan kedua dari teori piaget. Dalam tahapan ini, anak mulai mempresentasikan dunia mereka dengan katakata, bayangan, dan gambar-gambar. Anak mulai bisa mengembangkan dasar- dasar ketrampilan membaca, menulis dan menggambar dan menghitung. Masa ini disebut masa prasekolah dan masa sekolah. Anak mulai berinteraksi dengan teman sebayanya dan bekerjasama, dan juga anak berlompat, berlari, dan bermain bersama.

2) Perkembangan Psikososial

\footnotetext{
${ }^{7}$ Marzuki, Pendidikan Karakter Islam, (Jakarta: Amzah 2017), 80.
} 
Masa anak-anak adalah masa perkembangan dari usia 2 tahun sampai dengan usia 6 tahun, pada masa-masa ini perkembangan biologis dan fisik berjalan dengan sangat cepat dan pesat, akan tetapi secara sosiologisnya anak-anak masih sangat terikat dengan lingkungannya terutama keluarga. Adapun perkembangan psikososial yang terjadi pada masa ini meliputi beberapa hal yaitu : (a) Perkembangan Emosi: Selama awal masa kanak-kanak emosi sangat kuat. Saat ini merupakan saat ketidak seimbangan karena anak-anak "keluar dari fokus" dalam arti bahwa ia mudah terbawa ledakan-ledakan, emosional sehingga sulit dibimbing dan diarahkan. Jadi emosi yang meninggi pada masa kanak-kanak awal itu ditandai dengan meledaknya amarah yang kuat, ketakutan yang hebat dan rasa iri hati yang tinggi. Pada masa-masa ini anakanak sulit untuk dibimbing dan diarahkan, mereka cenderung akan marah, memberontak dan tersinggung jika diperingati, hal ini disebabkan anak-anak keluar dari fokus mereka; (b) Perkembangan Sosial: Dasar untuk sosialisasi pada anak-anak diletakkan dengan meningkatnya hubungan antara anak dengan teman-teman sebayanya dari tahun ke tahun. Anak tidak hanya lebih bermain dengan anak-anak lain tetapi juga lebih banyak bicara. sosialisasi pada awal masa anak-anak awal ditandai dengan meningkatnya intensitas hubungan dengan teman-teman sebayanya, dan perkembangan ini meningkat dari tahun ke tahun. ${ }^{8}$

3) Perkembangan Permainan

Permainan bagi anak-anak adalah suatu bentuk aktivitas yang menyenangkan yang dilakukan Hal ini adalah karena bagi anak-anak proses melakukan sesuatu lebih menarik dari pada hasil yang akan didapatkannya ${ }^{9}$. Jika ditarik garis besarnya, maka permainan memiliki peran yang tidak kalah penting dalam perkembangan pada awal masa anak-anak, permainan dapat berpengaruh terhadap perkembangan kognitif, perkembangan sosial dan juga perkembangan emosional pada anak-anak. Misalnya anak yang sangat cerdas lebih menyukai permainan sandiwara, kegiatan-kegiatan kreatif dan buku-buku yang dapat memberikan informasi dari pada yang bersifat hiburan.

\footnotetext{
${ }^{8}$ Elizabeth B. Hurlock, Psikologi Perkembangan Edisi V, (Jakarta: Erlangga,1996), 117.

${ }^{9}$ Desmita,Psikologi Perkembangan, (Bandung: Rosda Karya,2005), 144.
} 
4) Perkembangan Moral

Awal masa anak-anak ditandai dengan apa yang oleh Piaget disebut "moralitas melalui paksaan" Dalam tahap perkembangan moral ini anak-anak secara otomatis mengikuti peraturan-peraturan tanpa berpikir atau menilai ${ }^{10}$. Pada masa ini anak-anak hanya mengikuti peraturan yang telah ada, tanpa ia mengetahui guna ataupun fungsi dan juga tanpa menilai apakah peraturan tersebut benar atau salah.

\section{METODOLOGI PENELITIAN}

Jenis penelitian ini adalah penelitian kualitatif. Penelitian kualitatif adalah suatu penelitian ilmiah yang bertujuan untuk mengumpulkan data dan menyesuaikan dengan konteks. Penelitian ini menggunakan metode deskriptif naratif yaitu data yang dikumpulkan adalah berupa kata - kata, gambar, dan bukan angka ${ }^{11}$. Dengan demikian laporan penelitian ini akan berisi kutipan - kutipan data untuk memberi gambaran penyajian laporan. Penelitian ini berlokasi di bimbingan belajar Anak Hebat unit 1418 Desa Plunturan Kecamatan Pulung Kabupaten Ponorogo. Penelitian ini mengambil 11 informan dengan kriteria orangtua sudah satu tahun mendaftrakan anak ke bimbingan belajar Anak Hebat unit 1418.

\section{HASIL PENELITIAN}

\section{Motivasi Orangtua Mendaftarkan Anak di Lembaga Bimbingan Belajar Anak Hebat Unit 1418}

Latar belakang orangtua mendaftarkan anak ke Lembaga Bimbingan Belajar Anak Hebat diantaranya: (a) Kebutuhan Berprestasi (Achievement), tujuan orangtua 01 memasukkan anak ke Lembaga Bimbingan Belajar Anak Hebat Unit 1418 salah satunya karena anak menggunakan aplikasi mainan di gadget berdurasi lama saat dirumah. Salah seorang informan nomor 01 menceritakan pengalamannya ketika berada dirumah anak suka menggunakan aplikasi mainan di gadget. Orangtua khawatir jika kebiasaan anak ini

\footnotetext{
${ }^{10}$ Elizabeth B. Hurlock, Psikologi Perkembangan,.... 121

${ }^{11}$ Lexy J. Moleong, Metodologi Penelitian Kualitatif Edisi Revisi (Bandung: Remaja Rosdakarya 2017), 11.
} 
dibiarkan saja akan berdampak pada nilai anak di sekolah. Sehingga orangtua memiliki inisiatif untuk mengenalkan dunia baru pada anak seperti memasukkan anak di Lembaga Bimbingan Belajar Anak Hebat unit 1418 agar anak mengenal orang - orang baru sehingga dapat memberi motivasi yang positif untuk mengubah keadaan anak yang menggunakan aplikasi mainan di gadget berdurasi lama saat dirumah.

Tindakan orangtua memasukkan anak ke Lembaga Bimbingan Belajar Anak Hebat unit 1418 didorong oleh keinginan agar anak tidak menggunakan aplikasi mainan di gadget berdurasi lama saat dirumah sehingga motivasi belajar anak dapat kembali berdasarkan penyebabnya motvasi ini termasuk dalam motivasi ekstrinsik karena adanya rangsangan dari luar diri orangtua yaitu anak yang suka menggunakan aplikasi mainan di gadget berdurasi lama saat dirumah. Hal ini sesuai dengan kebutuhan berprestasi (achievement) yaitu kebutuhan yang digunakan manusia untuk mengatasi sesuatu yang sulit dan menarik, menguasai, mengatasi rintangan, dan mencapai standar, berbuat sebaik mungkin bersaing mengungguli orang lain. ${ }^{12}$

Disini ditemukan bahwasanya orangtua memiliki suatu rintangan yaitu anaknya suka menggunakan aplikasi mainan di gadget berdurasi lama saat dirumah. Orangtua berusaha mengatasi rintangannya yaitu anak yang suka menggunakan aplikasi mainan di gadget berdurasi lama saat dirumah kemudian anak di masukkan ke lembaga bimbingan belajar Anak Hebat hal ini digunakan untuk mengatasi rintangan yang sulit. Orangtua memiliki standar terhadap anaknya, orangtua ingin anaknya nanti bisa baca tulis sebelum kelas satu agar anak dapat masuk ke sekolah favorit dan mendapatkan juara satu saat di kelas. Orangtua berinisiatif memasukkan anak ke bimbingan belajar Anak Hebat dengan harapan bisa mengurangi penggunaan gadget pada anak selain itu dengan dimasukkan ke bimbingan belajar anak dapat memiliki motivasi belajar yang bagus, sehingga dapat mengalihkan perhatian anak pada gadget.

(b) Kebutuhan Penonjolan Diri (exhibition), latar belakang orangtua nomor 02 memasukkan anak ke Lembaga Bimbingan Belajar Anak Hebat Unit 1418 karena orangtua mendapati bahwa banyak anak yang mengikuti les di Bimbingan Belajar Anak Hebat Unit 1418. Motivasi berdasarkan dari keburuhan Murray, hal tersebut sesuai

${ }^{12}$ Alwisol, Psikologi Kepribadian ..., 185 
dengan kebutuhan penonjolan diri (exhibition) yaitu kebutuhan untuk mengesankan, dilihat dan didengar, membuat orang lain kagum, bergairah, terpesona, terhibur, terkejut, terangsang, terpikat. Menjadi pusat perhatian, menonjolkan prestasi, menyatakan keberhasilannya. orangtua ingin dilihat oleh orang lain bahwa dia juga mampu membuat orang lain kagum. Dengan menonjolkan prestasinya yaitu dia juga bisa memasukan anaknya anaknya les di Bimbingan Belajar Anak Hebat Unit1418. Sehingga membuat orang lain terkesan.

(c) Kebutuhan Membuat Orang Lain Iba (succorance), ketidakmampuan orangtua nomor 03,04 , dan 05 dalam mendampingi anak dalam proses belajar dirumah mengakibatkan anak tidak mau belajar, karena orangtua tidak bisa mengajari pasrahkan pada saja guru les. Menurut Murray ini masuk kedalam kebutuhan membuat orang lain iba (succorance), yaitu kebutuhan yang berkaitan dengan orang lain bersimpati dan membuat orang lain mengerti dan membantu dirinya. Dengan begitu tutor di bimbingan belajar Anak Hebat mengerti akan kesulitan orangtua murid dan membantu orangtua dalam mengalami kesulitan orntua sehingga tutor yang akan mengajari anak belajar baca dan tulis dengan baik pada saat kegiatan belajar mengajar di Lembaga Bimbingan Belajar Anak Hebat Unit 1418.

(d) Kebutuhan keteraturan (Order), kebutuhan keteraturan adalah suatu kebutuhan untuk berbuat secara teratur dengan perencanaan yang cermat sebelumnya. Anak dengan usia prasekolah oleh orangtua nomor 06, 07, dan 08 sudah dipersiapkan belajar baca tulis ketika anak berusia 7 tahun atau sekolah kelas 1 di Sekolah Dasar anak sudah lancar membaca tanpa mengeja. Sehingga dengan anak memiliki kemampuan membaca yang baik anak tidak akan kesulitan mengikuti pelajaran di Sekolah Dasar.

(e) Kebutuhan Mengimbangi (counteraction), kebutuhan mengimbangi yaitu kebutuhan memperbaiki kegagalan dengan berjuang lagi, menghilangkan pelecehan, mengatasi kelemahan, menekan takut, mengembalikan nama baik, mempertahankan harga diri. Pengalaman orangtua nomor 09, 10, dan 11 saat mengajari anak di rumah menunjukkan bahwa anak susah diatur, malas belajar lebih suka bermain, kemudian ketika belajar anak kurang konsentrasi, anak sering komplain dan akhirnya bertengkar 
dengan orangtua dan menjadikan anak tidak mau belajar membaca dengan orangtuanya saat berada dirumah.

Orangtua telah gagal mengajari anak ketika dirumah, ketika anak belajar dengan orangtua dirumah pasti akan terjadi suatu petengkaran yang menjadikan anak tidak mau belajar saat dirumah sehingga orangtua mencoba memperbaiki kegagalannya dalam mengajar belajar baca anak. Orangtua mencoba berjuang kembali untuk mengatasi kegagalannya dengan cara memasukkan anak ke Lembaga Bimbingan Belajar Anak Hebat unit 1418 agar anak mau belajar membaca.

\section{Harapan Orangtua Mendaftarkan Anak di Lembaga Bimbingan Belajar Anak Hebat Unit 1418}

a. Anak Rajin Belajar Membaca

Orangtua mempersiapkan masa depan anak dengan memberikan pendidikan yang baik. Setiap orangtua pasti menginginkan anaknya berprestasi. Anak memiliki kemampuan yang baik dalam kemampuan membaca adalah suatu cita - cita yang diharapkan oleh orangtua murid. Ketika anak masuk dalam les anak belum memiliki kemampuan membaca yang baik. informan nomor 01, 03, 07, dan 09 berharap anaknya rajin belajar dan bisa memahami huruf abjad

b. Anak Lancar Membaca Tanpa Mengeja

Memilih bimbingan belajar untuk anak adalah suatu kebutuhan yang didalamnya terdapat harapan. Patokan membaca dengan lancar adalah membaca tanpa mengeja. Orangtua nomor 02, 04, 05, 06, 08, dan 10 disini mengharapkan bahwa anak - anak dibimbing oleh guru yang sudah terlatih menjadikan anak benar - benar lancar membaca. Dengan diberi buku les dari level 1 sampai level 9. Orangtua berharap dengan adanya buku yang berjenjang akan mempermudah anak belajar baca tanpa mengeja.

c. Anak Mampu Bersosialisasi dengan Teman Sebaya

Pengalaman orangtua nomor 11 yang melihat anak enggan untuk bersosialisasi dengan teman sebayanya ini akan membentuk karakter yang negatife terhadap anak. Awalnya saat berada dirumah anak lebih senang menggunakan aplikasi gadget, 
menonton televisi dan anak sangat malas untuk bermain dengan teman sebayanya. Orangtua mengambil inisiatif dengan memasukkan anak ke Bimbingan Belajar Anak Hebat Unit 1418.

\section{Hasil Perkembangan Anak Usia Prasekolah Setelah Belajar di Lembaga Bimbingan Belajar Anak Hebat Unit 1418}

\section{a. Perkembangan Moral}

Orangtua nomor 01 memaparkan anak sudah tidak menggunakan aplikasi mainan di gadget berdurasi lama saat dirumah. Karena anak telah merasa memiliki tanggung jawab untuk belajar buku les sehingga fokus anak sudah teralihkan pada buku modul les karena seusai les dibaca lagi didampingi orangtua anak.

Perkembangan moral anak sudah mulai berkembang karena berdasarkan teori belajar sosial tentang perkembangan moral tingkah laku moral merupakan respon atas stimulus, proses-proses penguatan, pengukuman, dan peniruan digunakan untuk menjelaskan perilaku moral anak ${ }^{13}$

Hal ini ditemui bahwa anak mendapatkan stimulus belajar baca di les ia memiliki kebiasan membaca setiap seminggu tiga kali ini merupakan bentuk - bentuk proses penguatan. Anak menjadi memiliki tanggung jawab tidak lagi untuk tidak menggunakan aplikasi di gadget berdurasi lama saat dirumah karena kegiatanya sudah dialihkan kepada buku les.

\section{b. Perkembangan Kognitif}

Anak Gemar baca buku les dan buku cerita anak, berdasarkan data yang sudah dianalisis orangtua nomor 02, 06, 08, 09, dan 10 banyak anak yang suka membaca buku modul atau buku les anak. Dalam perkembangan ini anak masuk dalam perkembangan kognitif yang digunakan adalah tahap pra-operasional piaget yang menyebutkan bahwa anak memiliki perkembangan pemikiran-pemikiran simbolik berjalan melampaui koneksi-koneksi sederhana dari informasi sensorik dan tindakan fisik.

Konsep stabil mulai terbentuk, pemikiran-pemikiran mental muncul, egosentrisme tumbuh, dan keyakinan-keyakinan magis mulai terkonstruksi. Anak mulai bisa

\footnotetext{
${ }^{13}$ Desmita,Psikologi Perkembangan, ... 144.
} 
mengembangkan dasar- dasar ketrampilan membaca, menulis dan menggambar dan menghitung. Hasil dari penelitian ini adalah anak suka membaca buku cerita. Seperti cerita dongeng Timun emas. Anak mengisi waktu luang mereka dengan membaca buku buku cerita.

Anak informan nomor 03, 04, 05, dan 07 sudah lancar membaca tanpa mengeja, hal ini juga masuk dalam perkembnagan kognitif anak karena anak usia prasekolah sudah mulai bisa mengembangkan dasar- dasar ketrampilan membaca, menulis dan menggambar dan menghitung. Dilihat hasil perkembangannya yang dahulu anak belum tau apa itu huruf abjad dengan dimasukkannya anak ke Lembaga Bimbingan Belajar anak sudah mampu membaca huruf abjad dan membacanya tanpa mengeja.

\section{c. Perkembangan Sosial}

Perkembangan sosial pada awal masa anak-anak awal ditandai dengan meningkatnya intensitas hubungan dengan teman-teman sebayanya, dan perkembangan ini meningkat dari tahun ke tahun ${ }^{14}$. Anak mampu berinteraksi dengan teman sebaya, yang dahulu anak informan nomor 11 masih malu - malu, yang enggan bermain bersama temannya dengan dimasukkan ke Lembaga Bimbingan Belajar Anak Hebat anak jadi mau berbaur dengan temannya anak menjadi mau berbagi dengan teman dan antri saat giliran belajar les. Ditempat les ada ruangan khusus yang digunakan anak untuk bermain dengan adanya mainan seperti itu anak menjadi mau berbagi dengan teman dan bermain bersama dengan temannya.

\section{PENUTUP}

Berdasarkan dari data hasil penelitian yang dilakukan oleh peneliti dengan menggunakan teknik wawancara yang peneliti laksanakan kepada orangtua murid yang belajar di Lembaga Bimbingan Belajar Anak Hebat Unit 1418 tentang motivasi orangtua memilih Lembaga Bimbingan Belajar Anak Hebat dapat diambil beberapa kesimpulan. Kesimpulan tersebut dipaparkan sebagai berikut:

\footnotetext{
${ }^{14}$ Elizabeth B. Hurlock, Psikologi Perkembangan, Edisi V, ... 117
} 
a. Latar belakang orangtua mendaftarkan anak usia prasekolah ke Lembaga Bimbingan Belajar Anak Hebat unit 1418 karena didorong adanya motivasi berdasarkan kebutuhan motivasi Henry Murray yaitu kebutuhan berprestasi (achivement), kebutuhan penonjolan diri (exhibition), kebutuhan membuat orang lain iba, kebutuhan keteraturan (order), dan kebutuhan mengimbangi (counteraction).

b. Harapan merupakan motivasi yang ada dalam diri seseorang (instrinsik). Faktor isntrinsik yang mendorong orangtua mendaftarkan anak usia prasekolah ke Lembaga Bimbingan Belajar Anak Hebat Unit 1418 memiliki harapan supaya anak rajin belajar membaca, supaya anak lancar membaca tanpa mengeja, dan supaya anak mampu bersosialisasi dengan teman sebaya.

c. Hasil perkembangan anak usia prasekolah setelah belajar di Lembaga Bimbingan Belajar Anak Hebat Unit 1418 yang sudah terealisasikan dengan bentuk bentuk perkembangan anak yang dapat disimpukan sebagai berikut : tugas perkembangan moral yaitu anak tidak menggunakan aplikasi mainan di gadget berdurasi lama saat dirumah, perkembangan kognitif yaitu anak gemar baca buku modul les dan buku cerita anak dan sudah lancar membaca tanpa mengeja, yang terakhir adalah perkembangan sosial yaitu anak sudah mampu berinterkasi dengan teman sebayanya.

Berdasarkan hasil penelitian ditemukan beberapa permasalahan yang belum terpecahkan, maka perkenankan peneliti mengajukan beberapa saran antara lain sebagai berikut :

a. Orangtua

Orangtua hendaknya dapat terus dan lebih meningkatkan perhatiannya terhadap kegiatan belajar dan bermain anak meskipun sudah les di bimbingan belajar Anak Hebat, Orangtua harus selalu memberikan bimbingan, memberikan nasihat pemberian dorongan, dan memberikan pengawasan terhadap anak. Tidak memaksakan perkembangan anak agar ia cepat bisa baca tulis, pelan-pelan biarkan anak berkembang sesuai dengan perkembangannya masing-masing. Selain itu orangtua senantiasa memperhatikan tumbuh kembang anak ke arah yang lebih baik dan selalu membina hubungan yang harmonis dengan anaknya.

b. Lembaga Bimbingan Belajar Anak Hebat Unit 1418 
Pihak bimbingan belajar Anak Hebat seharusnya melengkapi sarana prasarana yang dapat membantu perkembangan anak, bekerjasama dengan orangtua, dalam membentuk kepribadian anak yang berkarakter positif.

\section{DAFTAR RUJUKAN}

Alwisol. Psikologi Kepribadian. Malang: UMM Press, 2009.

Atkinson, Rita L, Richard C Atkinson, dan Ernest R Hilgrad. Pengantar Psikologi Edisi ke delapan Jilid 2. Jakarta: Erlangga, 1996.

Desmita. Psikologi Perkembangan. Bandung: Rosdakarya, 2005.

Djamarah, Syaiful Bahri. Pola Asuh Orangtua dan Komunikasi dalam Keluarga Upaya Membangun Citra Membentuk Pribadi Anak. Jakarta: Rineka Cipta, 2014.

Hurlock, Elizabeth B. Psikologi perkembangan Edisi V. Jakarta: Erlangga 1996.

Marliani, Rosleny. Psikologi Umum. Bandung: Pustaka Setia,2010.

Marzuki. Pendidikan Karakter Islam. Jakarta: Amzah, 2017.

Moeleong, Lexy J. Metodologi Penelitian Kualitatif. Bandung: Remaja Rosdakarya, 2002.

Sobur, Alex. Psikologi Umum dalam Lintasan Lintasan Sejarah. Bandung: Pustaka Setia, 2003. 